\title{
Factors Influencing Equity Return Correlations between China's Pairs of A- and B-Share Markets: Effect of QFII's Implementation
}

\author{
Jung-Lieh Hsiao ${ }^{1}$, Teng-Tsai Tu ${ }^{1} \&$ Mei-Chun Chen ${ }^{1}$ \\ ${ }^{1}$ Graduate Institute of International Business, National Taipei University, Taiwan \\ Correspondence: Jung-Lieh Hsiao, Graduate Institute of International Business, National Taipei University, Taiwan.
}

Received: December 15, 2016

Accepted: December 30, 2016

Online Published: April 7, 2017

doi:10.5430/ijfr.v8n2p105

URL: https://doi.org/10.5430/ijfr.v8n2p105

\begin{abstract}
This paper was intended to examine factors influencing the correlations between A- and B-shares of individual firms, and explore the effects of Qualified Foreign Institutional Investor's (QFII) implementation on correlations. The empirical results show that interest rate differential, relative turnover rate, relative return volatility, and market sentiment had impacts on correlation both before and after the QFII's implementation. After its implementation, correlations became more sensitive to premium, relative turnover rate and market sentiment. Furthermore, the estimated constant term for overall market correlation became more negative (raw values from - 0.3413 to -0.8815 ), indicating an increasing correlation between A- and B-shares' returns. The policy implications are that much benefit of diversification into emerging markets such as paired A-and B-shares can be accomplished, together with taking several influential factors into account.
\end{abstract}

Keywords: QFII, premium, relative turnover rate, market sentiment, Paired A-and B-shares

JEL: G11, G14, G18

\section{Introduction}

Both the Shanghai Stock Exchange (SHSE) and the Shenzhen Stock Exchange (SZSE) were set up in December 1990 and April 1991, respectively. In the beginning, only eight firms were listed on the SHSE and six firms listed on the SZSE. The number of listed firms has been constantly increasing, and by the end of April 2013, a total of 954 and 1537 firms were listed on the SHSE and the SZSE, respectively. Originally, the A-shares were only available to domestic residents trading in RMB, while the B-shares were restricted to foreign investors trading in USD on the SHSE and in HKD on the SZSE.

The gradual development of the Chinese equity market has exerted a strong influence on the country's economic growth and corporate governance. The Chinese equity market has expanded rapidly and has gained the attention of the world equity market. According to the 2015 statistics of the World Federation of Exchanges, both the Shanghai and Shenzhen markets have ranked in the global top five equity markets by market capitalization (in USD millions). In addition, the MSCI has planned to include China A-shares in its indices in the near future, which will re-induce international asset reallocation. Thus, foreign investors adopting a global asset allocation strategy have paid more attention to this immense potential for growth. International investment wisdom suggests that interactions between assets are significant factors to be considered when managing diversification. In this light, re-examination of the effects of the Qualified Foreign Institutional Investor (QFII) program on the correlations of A- and B-share returns is warranted.

Under strict foreign exchange controls to protect the A-share market from being affected by foreign capital, the Aand B-share markets were separated prior to February 19, 2001. The severe regulations and the small number of tradable securities led to some problems in the B-share market, such as illiquidity, thin trading volumes, higher transaction costs, and an even higher B-share discount for investors. On the other hand, after entering the World Trade Organization (WTO), the Chinese authorities made great efforts to keep to their commitments, such as liberalizing their financial markets.

To revitalize the B-share market and attract financial capital that comes from domestic individual and foreign investors, the China Securities Regulatory Commission (CSRC) announced on February 19, 2001 that domestic citizens would be allowed to trade the B-shares. The policy was expected to increase the trading volumes of B-shares 
and reduce the transaction costs as well as B-share price discount. However, as proven by empirical studies, the price spread between the A and B-shares widened. Further, domestic investors take the advantages of price disparity and trade in the B-share market, which could spur speculative activities, thus resulting in uncertainty concerning volatility. The vigorous arbitrage activities that were worsening the investment environment frightened foreign investors.

Because the B-share policy did not work well as expected, the State Administration of Foreign Exchange (SAFE) formulated the QFII program in November 2002, which was used to introduce foreign investments and open the domestic capital market in a restricted way. On July 7, 2003, the first transaction of Swiss Bank Corporation was completed; this was the first flow of foreign capital into the A-share market. On April 26, 2005, a $\$ 4$ billion investment quota was distributed, and in the same year the investment quota was expanded to $\$ 10$ billion. Subsequently, the investment quota increased to $\$ 30$ billion in 2007 , and finally it expanded again to $\$ 80$ billion in 2012. It was anticipated that the introduction of QFII would improve the functioning of the capital market, including increased innovative investment ideas and longer-term strategic investments. QFII investors would be expected to play a positive role in prompting the capacity of domestic corporate governance. Under bilateral liberalization, the interactions between the A- and B-share markets should have the potential to become stronger.

According to previous studies (e.g., Law \& Ngahab, 2008; Henry, 2002; Li, 2002; Bekaert \& Harvey, 1997; Kassimatis, 2002; Huang \& Yang, 2000; Sun, Tong \& Yan, 2009; Chiu, Lee \& Chen, 2005; Chen \& Liu, 2009; Ahlgren, Sjö \& Zhang, 2009; Shen \& Chen, 2003; Tam, Li, Zhang \& Yu, 2010; Peng, 2008; Lu \& Su, 2008; Shen \& Lan, 2007; Huang, 2007; Wang \& Han, 2008), market liberalization indeed had influential effects on the financial market, irrespective of whether the impact was positive or negative. This study is motivated by Sun, Tong, \& Yan (2009), wherein they investigated whether the B-share market's partial liberalization, which took place on February 19, 2001, improved the market quality (Note 1). They defined the opening of the B-share market as "reverse" liberalization. However, QFII is more precisely a regular direction of liberalization. The degree of A- and B-share market interactions can be estimated along several different dimensions. As noted by Adam et al. (2001) and Baele et al. (2004), no widespread agreement can be reached about a single correct measurement. Furthermore, as mentioned by Bekaert and Harvey (2003), the announcement of financial liberalization may not be the effective date of its implementation, such that foreign capital inflows may begin to increase some time later. Thus, we extend Sun, Tong, \& Yan (2009)'s research by examining whether or not the practical implementation of the QFII scheme, which began on July 7, 2003, increases the interaction between the A-B pairs of individual firms of stock market and in the meantime, we explore several factors that could affect correlations of paired A and B-shares' returns. This paper is empirically significant for the following two reasons. Firstly, little is known about the effect of QFII's implementation on correlations of A-B pairs of individual firms, especially focusing on the effect of factual foreign capital inflow. Secondly, it is interesting to explore several factors that may be presumably related to interactions of paired A- and B-share returns, wherein international diversification can be affected by these factors.

The empirical research is carried out through panel data modeling by observing each sub-period. As the QFII scheme belongs to inward investment, an inflow of foreign capital will indirectly introduce distinct investment notions, leading to changes in domestic investors' behavior. The empirical results suggest that after QFII's implementation, correlations of paired A- and B-share returns were more sensitive to premium, relative turnover rate and market sentiment. Besides, the estimated constant term for overall correlation became more negative (raw values from -0.3413 to -0.8815 ), indicating an increasing correlation between A- and B-share returns. It implies that benefit of diversification into emerging markets such as paired A-and B-shares can be accomplished and that the above-mentioned factors need to be carefully considered when dealing with international investment.

The remainder of this paper is arranged as follows. The section II involves a literature review regarding empirical findings of liberalization schemes introduced into emerging markets and China. In section III, we briefly discuss the procedure of selecting appropriate panel data models, and the ensuing empirical model used in this study. Section IV presents empirical results and analyses. Finally, based on the aforementioned analyses, we draw conclusions with a summary in section $\mathrm{V}$.

\section{Brief Literature Review}

The following is concise review on financial market liberalization in some emerging markets. Section 2.1 presents deregulation in developing markets except for China; section 2.2 presents the research related to the policy of opening the B-share market and the QFII program in Chinese equity markets. 


\subsection{Liberalization in Emerging Markets}

Many articles have been written about stock market liberalization in developing countries and emerging markets. Law \& Ngahab (2008) utilized an EGARCH model to show that stock return volatility declined after the Kuala Lumpur Stock Exchange opened Malaysia up to foreign investors. Henry (2002) showed that the execution of capital market liberalization in emerging markets caused the equity price index to have excess returns, which is consistent with the expectation of international asset pricing models. Li (2002) observed a significant decrease in volatility three months after Taiwan unlocked its stock market, and found that market efficiency was significantly enhanced. In brief, an inflow of foreign capital could stabilize the stock market. Bekaert \& Harvey (1997) demonstrated that in 13 of their 17 sample countries, liberalization of equity markets led to a substantial drop in volatility; this was especially significant in 5 emerging markets (Taiwan, Mexico, Portugal, Argentina, and Brazil), after controlling for potential factors influencing the time-varying volatility. Kassimatis (2002) demonstrated that volatility was reduced after relaxing financial markets in five out of six sample developing countries. The results were partly consistent with those of Bekaert \& Harvey (1997). Huang \& Yang (2000) found that four of the ten studied markets appeared to decrease volatility, while three markets experienced increasing volatility after liberalization. Based on the above, the liberalization of capital markets had either positive or negative impacts on the stabilization of the market and the investment environment.

\subsection{Market Liberalization in China}

While becoming a member of the WTO, China was required to achieve certain levels of market liberalization. China thus opened its financial markets and progressively relaxed the foreign exchange controls over capital accounts. China expected that the policy of liberalization would result in mature investment concepts, longer-term investments, and superior investment skills so as to make the domestic financial markets more stable and sound.

There are large amounts of empirical studies concerning the impact of opening the B-share market to nationals on February 19, 2001. Sun, Tong, \& Yan (2009) found the B-share market quality to be improved - and not at the expense of the other domestic markets - subsequent to liberalization. They also examined the correlation between Aand B-share markets, and found that it increased in the post-liberalization period. Chiu, Lee, \& Chen (2005) confirmed that return correlation between four A- and B-share indices increased during post-event periods, and the transmission of information between A- and B-share markets accelerated, which shortened the persistence of the impact. Chen \& Liu (2009) showed that before permitting nationals to trade B-shares with foreign currency accounts, co-integration had existed between only a small number of dually-listed A- and B-shares, while after liberalization, most of them were more co-integrated. They further found that in pre-liberalization, the B-share market was ahead of the A-share market, and in post-liberalization, the situation was reversed. As indicated by Ahlgren, Sjö, \& Zhang (2009), after February 2001, A-share premiums became stationary, and a co-integration relationship existed between the prices of A- and B-shares. The policy of liberalization also reduced the degree of information asymmetry between the A- and B-share markets. By using asymmetric threshold co-integration model, Shen \& Chen (2003) found the co-integration relationship between markets to become stronger after the B-share market was open to local residents.

Owing to the QFII program only being implemented within emerging markets and developing countries, there are few foreign scholars studying the QFII scheme in China. The following are literature reviews undertaken by Chinese researchers. Tam, Li, Zhang, \& Yu (2010) show that the QFII scheme failed to attract longer-term investments, that QFII's benefit to market stability was temporary due to the relatively small shares in the market, and that the introduction of QFII was helpful to integrate the Chinese stock market into global markets. He et al. (2014) documented that China's financial liberalization had greatly promote international stock interdependence in the post-WTO's accession period. In addition, China's economic overheating (in year of 2007) and economic stimulus plan (in years of 2008-2009) as well as market overreaction significantly contributed to the rise in international stock market interdependence. Peng $(2008)$ utilized a $\operatorname{GARCH}(1,1)$ model to show that when the first order of the Swiss Bank Corporation (SBC) traded on the A-share market on July 9, 2003, the return volatility of the Shanghai Composite Index decreased. Moreover, approval of the extra 6 billion USD quotas of investment on September 7, 2005 reduced return volatility of both the Shanghai and the Shenzhen Composite Index. Lu \& Su (2008) found that with QFII investors entering more deeply into the markets, volatility became more persistent, indicating the failure of QFII programs to stabilize the markets. Shen \& Lan (2007) argued that the introduction of QFII was not significant to return volatility of the Shanghai A-share Index. The reason for this result might be due to the minor size of the capital that QFII investors placed into the stock market. Study conducted by Huang (2007) showed an increase in persistence of volatility after the QFII scheme's implementation in both mutual fund and A-share markets. Wang \& Han (2008) found return volatility of the Shanghai and Shenzhen A-share indices were lower than those of the 
corresponding B-share indices during 2003-2005. Zou et al. (2016) used unique data spanning from 2003 through 2014 to examine the preferences of domestic and foreign institutional holdings in China; empirical findings showed similar preferences of both institutions on certain stock characteristics, but difference towards industry allocations.

Previous studies related to the China's QFII program mainly focused on changes in volatility and persistence of volatility and institutional preferences on holding. Furthermore, empirical results are primarily subject to small size of funds flowing into markets. As time goes by, in the light of the increasing investment quota of QFII, funds flowing into the equity market are continuously growing. Consequently, we take this factor into consideration when examining the variation in the degree of interactions between A- and B-shares only, not the market as a whole.

\section{Methodology - Panel Modeling}

Panel data regression is used to examine factors that significantly affect the correlations between firms and inspect if these correlations could be influenced by QFII's implementation. The empirical results may provide investors and policymakers with some implications for appropriate investment strategies and policy choices, respectively. Before undertaking the main empirical research, we conducted several tests to confirm data's stationarity and selection of panel data model. These two types of tests are briefly described in section 3.1 while section 3.2 displays the construction of our empirical model.

\subsection{Panel Data Model Selection}

In traditional regression analysis, variable series are assumed to be stationary, or else spurious regression will be obtained. Panel unit root tests such as Levin, Lin and Chun's (LLC, 2002) and Im, Pesaran, and Shin (IPS, 2003) are adopted to check whether variables are stationary. The null hypothesis of both tests is that there exists a unit root, meaning a non-stationary data. Then, the selection process of the panel data model includes (1) pooled regression model versus fixed effects model through $F$ test, (2) pooled regression model versus random effects model through Breusch-Pagan LM (Breusch \& Pagan, 1980) test and (3) if both F-test and LM test indicate that a pooled regression model is not suitable, we then use the Hausman test to determine which should be adopted between the fixed and random effects models.

\subsection{Establishment of Empirical Model}

We attempt to analyze factors affecting the correlation between A- and B-shares of paired firms, such as exchange rate volatility, price discount, interest rate differential, relative turnover rate, relative return volatility, and market/firm sentiment. Besides, we add company size and global factor (represented by volatility of S\&P 500 index return) as control variables. Thus, the model is constructed as follows:

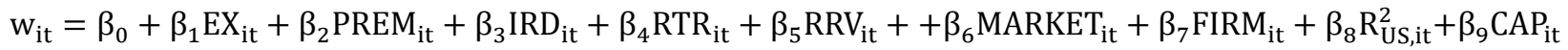

$$
\begin{aligned}
& +u_{i t} \\
& i=1,2, \cdots, 64 ; t=1,2, \cdots, 180
\end{aligned}
$$

$\mathrm{w}_{\text {it }}$ is monthly correlation of the $\mathrm{i}^{\text {th }}$ firm between A- and B-share returns at time $\mathrm{t}$ and is calculated by daily stock returns denominated in RMB currency for A-shares and USD or HKD for B-shares. To make the series closer to a normal distribution, we adopt the transformation of Otto et al. (2001). After conversion, we replace $w_{i t}$ with $\rho_{i t}$.

$\rho_{\mathrm{it}}=\ln \left(\frac{1+\mathrm{w}_{\mathrm{it}}}{1-\mathrm{w}_{\mathrm{it}}}\right)$, where $\mathrm{w}_{\mathrm{it}}$ is correlation before transformation. The stock return is calculated as follows:

$$
\mathrm{R}_{\mathrm{t}}=\ln \left(\frac{\mathrm{P}_{\mathrm{t}}}{\mathrm{P}_{\mathrm{t}-1}}\right) \times 100
$$

The following are detailed descriptions of explanatory variables:

1) EX denotes monthly exchange rate volatility, calculated by:

$$
\mathrm{EX}=\left|\ln \left(\frac{\mathrm{S}_{\mathrm{t}}}{\mathrm{S}_{\mathrm{t}-1}}\right)\right| \times 100
$$

where $\mathrm{S}_{\mathrm{t}}(\mathrm{USD} / \mathrm{RMB})$ is the exchange rate at time $\mathrm{t}$ for firms listed on SHSE while $\mathrm{S}_{\mathrm{t}}(\mathrm{HKD} / \mathrm{RMB})$ is for firms listed on SZSE.

Bodart and Reding (1999) found that rise in volatility of the Deutschmark was accompanied by a decline in international correlations between Germany and other sample countries, such as France, Belgium, UK, Sweden, and 
Italy. In addition, Jithendranathan (2005) showed that exchange rate volatility between Russia and the US had positive effects on Russia/US stock index correlation. Moreover, Wälti (2011) found that lower exchange rate volatility is linked to stronger market co-movements. This is because decrease in exchange rate uncertainty can reduce transaction costs, leading to a stronger correlation.

While the above-mentioned studies focus on pairs of countries, this study is concerned with two markets within a single country. We expect that given tone in with gradual exchange rate reforms, the implementation of QFII may have resulted in an increase in exchange rate volatility since the inflow of international capital needs to be converted into Chinese Yuan, and may be invested into the A-share market. Hence, in line with the previous findings, we expect that volatility of exchange rate is positively or negatively related to correlations under the implementation of the QFII program.

2) PREM denotes the monthly price discount between A- and B-shares of the firm.

$$
\text { PREM }=\frac{P_{b}-P_{a}}{P_{a}} ; P_{b} \text { is converted to Chinese Yuan }
$$

$\mathrm{P}_{\mathrm{b}}\left(\mathrm{P}_{\mathrm{a}}\right)$ is the price of a $\mathrm{B}(\mathrm{A})$ share. $\mathrm{P}_{\mathrm{b}}$ is usually smaller than $\mathrm{P}_{\mathrm{a}}$, so PREM is usually negative. Given all other things being equal, if there is a price spread, investors could make use of the QFII program to perform arbitrage activities, which makes the premium less negative (i.e., the PREM becomes larger). Thus, we predict that premium may negatively influence paired share's correlation. Another scenario is that QFII's implementation may increase the degree of information sharing between A- and B-share of a firm, which supports the price synchronicity and correlation should be high (Chan, et al., 2013). Note that high price synchronicity may correspond to weaker institutional environment documented by Dang, et al. (2015). Thus, it is also expected that positive relation could be found between correlation and PREM.

3) IRD stands for monthly interest rate differential. We use 3-month LIBOR (HIBOR) as a risk-free interest rate whilst China's equivalent, SHIBOR (Shanghai Interbank Offered Rate) was established in 2006. Due to the length of SHIBOR data being insufficient for our study, we replace SHIBOR with the 3-month time deposit rate.

$$
\begin{aligned}
I_{R} D_{t}^{S H S E} & =R_{U S, t}-R_{C H, t} \\
I R D_{t}^{S Z S E} & =R_{H K, t}-R_{C H, t}
\end{aligned}
$$

where $R_{U S, t}\left(R_{H K, t}\right)$ is equal to 3-month LIBOR (HIBOR) while $R_{C H, t}$ is proxy for 3-month time deposit rate. Pontiff (1996) regarded interest rate as an opportunity cost of arbitrage. Assets that are more costly to arbitrage will exhibit discounts that are more pronounced. Li et al. (2006) viewed interest rate spread as the difference in the costs of holding stocks. They found that price disparity between A- and H-shares is related to interest rate spread.

Due to outbreak of the 2007 financial crisis, the US and Hong Kong cut their interest rates to almost zero, which led to the interest rate spreads becoming negative. A decrease in interest rate spread means that there is a smaller difference in costs of holding stocks between Chinese local investors and foreign investors. As a consequence, when QFII was carried out, foreign investors might have become more willing to invest in Chinese stock market where price discounts existed between A- and B-shares. We expect that the interest rate differential is negatively related to paired-share's correlation.

4) RTR denotes the monthly relative turnover rate, calculated by:

$$
\mathrm{RTR}=\frac{\text { Turnover rate of B share }}{\text { Turnover rate of A share }}
$$

Stock's turnover rate is defined as the total number of shares traded over one particular month divided by the total number of shares outstanding. To avoid a zero monthly turnover rate, we follow Llorente et al.'s (2002) adjustment by adding a constant $(0.00000255)$ to the turnover rate. Further, to make the series stationary, we measure turnover rate logarithmically:

$$
\text { Turnover rate }=\log (\text { turnover rate }+0.00000255)
$$

We use turnover rate as a proxy variable of liquidity. Amihud and Mendelson (1986) believed that illiquid stocks should have higher expected return. To compensate investors for higher transaction costs, pricing becomes lower. However, Chan et al. (2008) thought that liquidity is valuable, so higher liquidity has higher expected return and pricing. Thus, ADR with high liquidity yields a greater discount. 
If the turnover rate of a B-share over an A-share is larger than one, it indicates that one firm's B-share is more liquid than its A-share counterpart. After the QFII's implementation, the turnover rate of both A- and B-share may increase but to a time-varying extent. Thus, we cannot infer the direction of variation.

5) RRV denotes the relative return volatility, calculated by:

$$
R R V=\frac{\text { volatility of B share }}{\text { volatility of A share }}
$$

Following Young and Johnson (2004), we use RRV ratio to measure the relative volatility of the B- and A-shares. Stock volatility is defined as monthly variance of the stock as calculated by daily data. Cappiello et al. (2006) showed that stocks' return volatilities and correlations move together, while Knif and Pynnönen (2007) reported supporting findings that high volatility tends to increase correlations between markets. He, et al. (2003) documented that high volatility disparity between B- and A-share returns was mainly attributed to informed trading cost and when accounting for informed trading as well as other component costs, the volatility disparity disappeared. The implementation of the QFII program may gradually reduce the trading cost difference between the A- and B-share, which might in turn increase the cross correlations.

6) MARKET denotes market sentiment, measured by:

$$
\begin{aligned}
\text { MARKET } & =\frac{(\mathrm{P} / \mathrm{E}) \text { of index of A shares }}{(\mathrm{P} / \mathrm{E}) \text { of index of } \mathrm{B} \text { shares }} \\
\mathrm{P} / \mathrm{E} & =\text { Price } / \text { Earning per share }
\end{aligned}
$$

Studies of Wei (2000) and Wang and Jiang (2004) indicate that market sentiment may have explaining power for the differences in the prices of cross-listed shares. According to Arquette et al. (2008), market sentiment can be defined as in equation (10). They found that market sentiment is negatively related to the premium between an A-share and its corresponding $\mathrm{ADR} / \mathrm{H}$ share. If market sentiment is larger than one, a positive sentiment may be present in the overall A-share market, suggesting that B-shares could be sold at a relatively lower price than their A-share counterparts. Investors in the B-share market if not being immediately subject to the effects of the A-share market could allow prices to differ across the two markets. Based on previously discussed relatedness between PREM and correlation, it is reasonably predicted that market sentiment could be positively or negatively related with paired Aand B-share correlations.

7) FIRM denotes company sentiment, measured by:

$$
\text { FIRM }_{t}=\frac{[\ln (\mathrm{P} / \mathrm{E})]_{\mathrm{t}-1} \text { of individual firm }}{[\ln (\mathrm{P} / \mathrm{E})]_{\mathrm{t}-1} \text { of index of A shares }}
$$

In accordance with Arquette et al. (2008), we define company sentiment as the above formula. They found that company sentiment is negatively related to the premium between an A-share and its corresponding ADR/H share. However, this measure may include firms with negative earnings, and we thus choose to use another measure of company sentiment such as price-to-sale ratios that would still come with positive values. As suggested by Arquette et al. (2008), we substitute price-to-sales ratio for P/E ratio.

Both A- and B-share liquidity may be driven up by company sentiment; meanwhile, company sentiment may increase partly due to market sentiment as well as the QFII's effect. In this case, the price synchronicity and liquidity go together, which bring positive impact on correlation. However, when investors drive up the A-share price of an individual company relative to the corresponding B-share price, then the B-share would sell at a greater discount relative to the A-share, which might stimulate speculative trading actions. Thus, the short-term adjustment between A- and B-share prices will increase. It is implied that company sentiment is negatively connected to A- and B-share correlations.

8) $R_{U S}^{2}$ denotes the volatility of the S\&P 500 index, and we use daily data to calculate it, as shown in equation (13). Due to the gradual opening of Chinese financial markets, we expect that the Chinese stock market would be more integrated with the international market and might be more influenced by global factors, and that positive correlation could be linked to A- and B-share returns. 


$$
R_{U S, t}^{2}=\left(\ln \left(\frac{\mathrm{P}_{\mathrm{t}}}{\mathrm{P}_{\mathrm{t}-1}}\right) \times 100\right)^{2}
$$

9) CAP denotes a firm's market capitalization, measured by:

$$
\mathrm{CAP}=\ln \text { (market capitalization) }
$$

In addition to $\mathrm{R}_{\mathrm{US}}^{2}$, we also add company's market capitalization to the empirical model as another control variable. On average, larger companies would have less trading cost and thus have more cross information.

\section{Empirical Results and Analysis}

This section describes the data and details the empirical analysis of our panel data modeling.

\subsection{Data Description}

Monthly data was used to examine factors that influence correlation between A- and B-shares of individual firms. The sample contained 64 pairs of firms with A- and B-shares listed on either the Shanghai or Shenzhen stock exchanges, 35 of which are listed on the SHSE and 29 on the SZSE. The data covered the period from January 1998 to December 2012. The sample period was divided into two sub-periods: the first period ran from January 1998 to June 2003 and the second period ran from July 2003 to December 2012. The first capital inflow of Swiss Bank Corporation into the A-share market was traded on July 9, 2003, the date the QFII scheme was officially brought into effect; thus, we viewed July 2003 as the dividing point.

Except for the S\&P 500 index, which was collected from DataStream, all other data were collected from the Taiwan Economic Journal (TEJ) database. Firms selected for this study have been listed on the stock market since 1998. If a company's data was missing for over $5 \%$ of the entire observation period, it was excluded from the sample. Note that all empirical results were conducted in Eviews 7. Figures 1 to 12 are trend plots of the variables, where we averaged all the cross-sectional data at each observation period (monthly) to observe trends in the variables while some variables, such as exchange rates and interest rates, are only time series data.

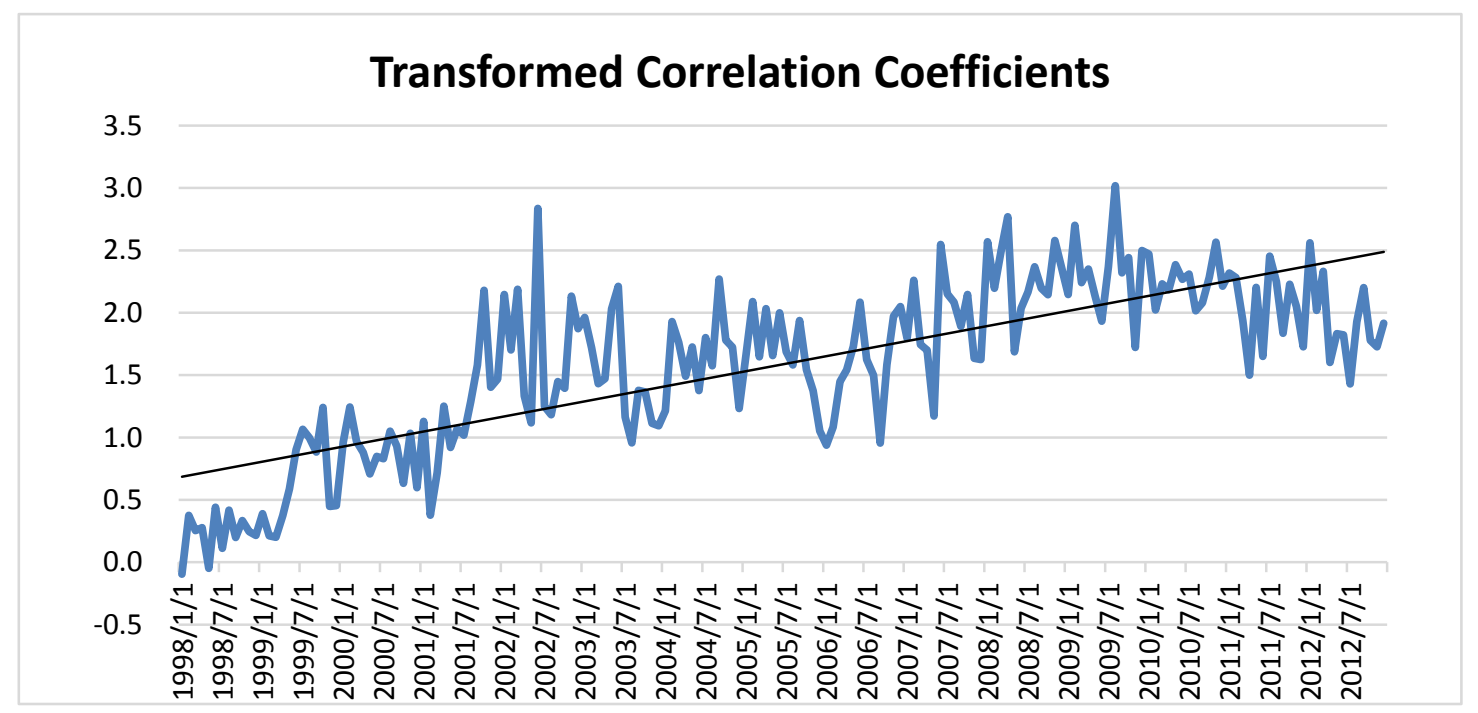

Figure 1. Plot of monthly averaged Paired A- and B-share correlations

As shown in Figure 1, the average monthly paired A- and B-share correlation has increased significantly since 2001 and goes up again right after July 2003. This might be due to the opening of B-share markets to local Chinese investors and the subsequent QFII policy, which facilitated interactions between A- and B-shares. 


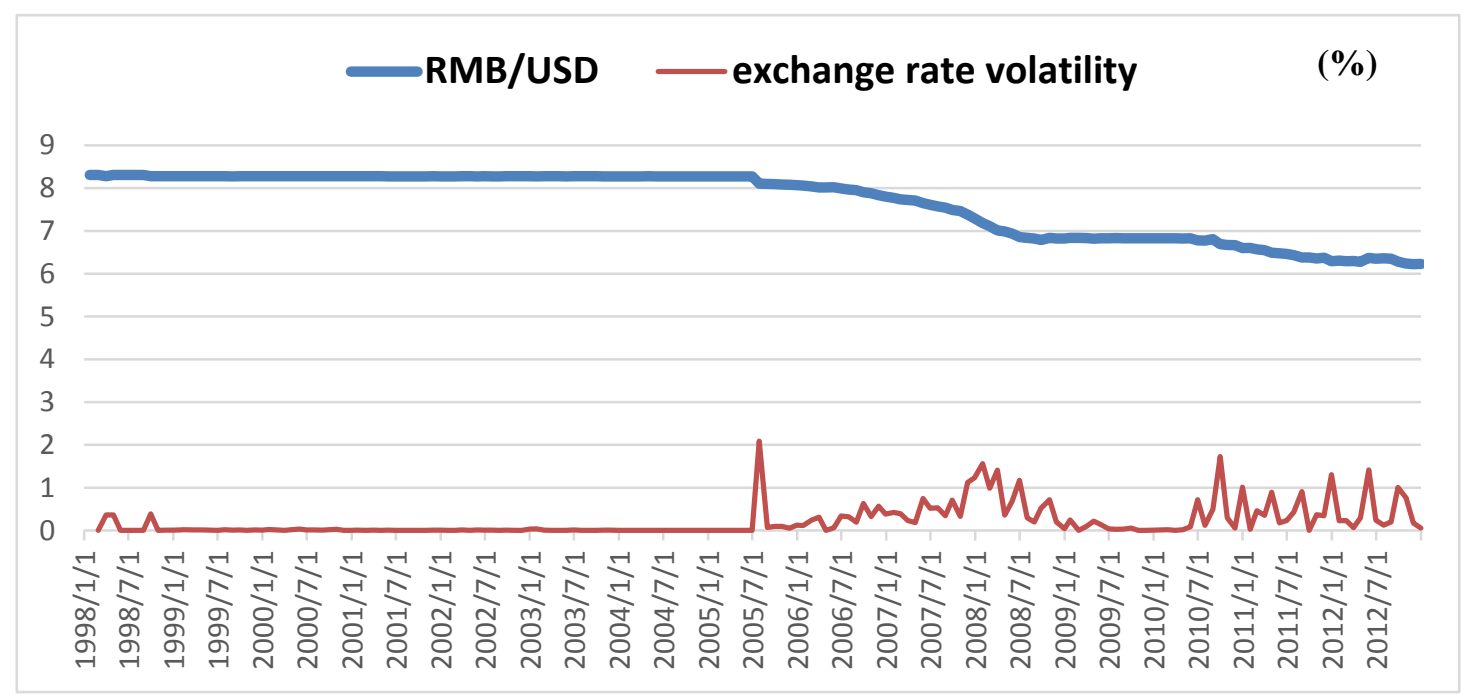

Figure 2. Plot of monthly exchange rate (RMB/USD) and volatility

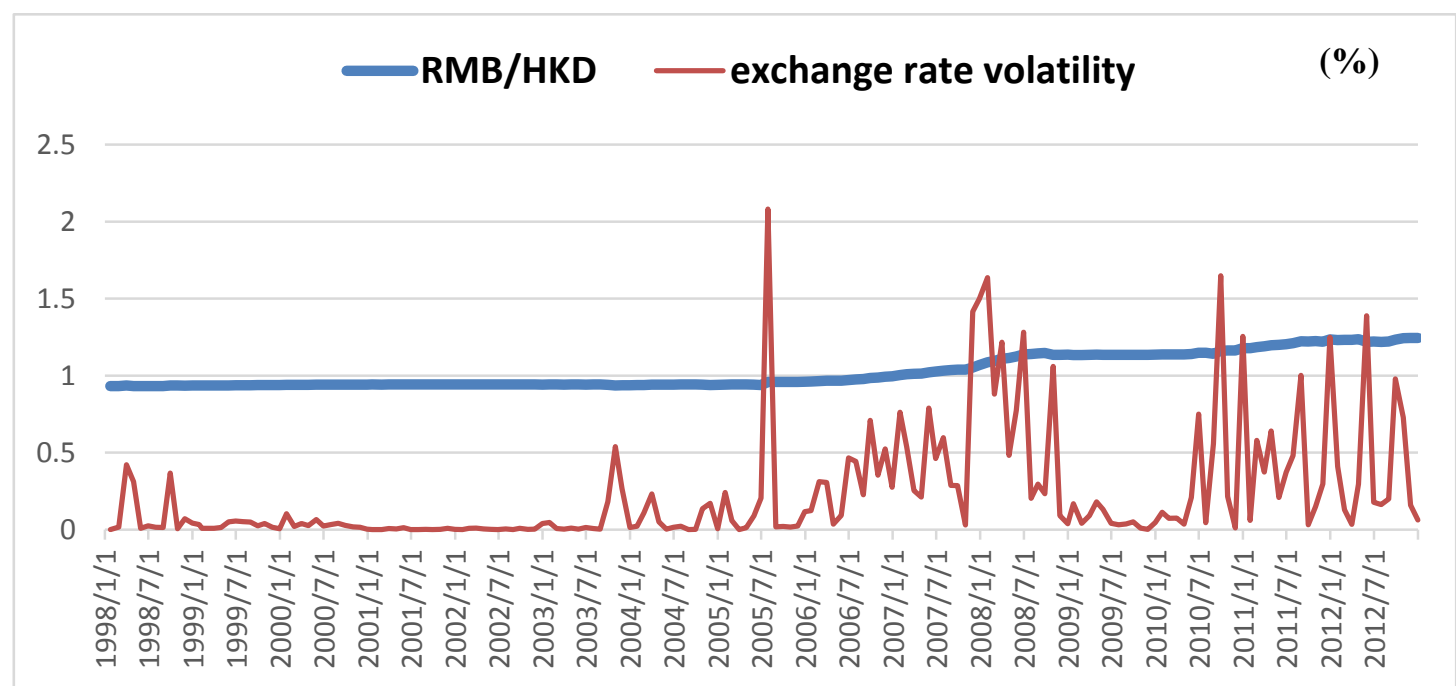

Figure 3. Plot of monthly exchange rate (RMB/HKD) and Volatility

Exchange rate volatilities between RMB and USD and between RMB and HKD became visibly larger since 2005 , which was consequence of exchange rate reform. On July 21, 2005, the People's Bank of China announced the rate of 8.11 RMB per 1 USD and permitted floating within $0.3 \%$. 


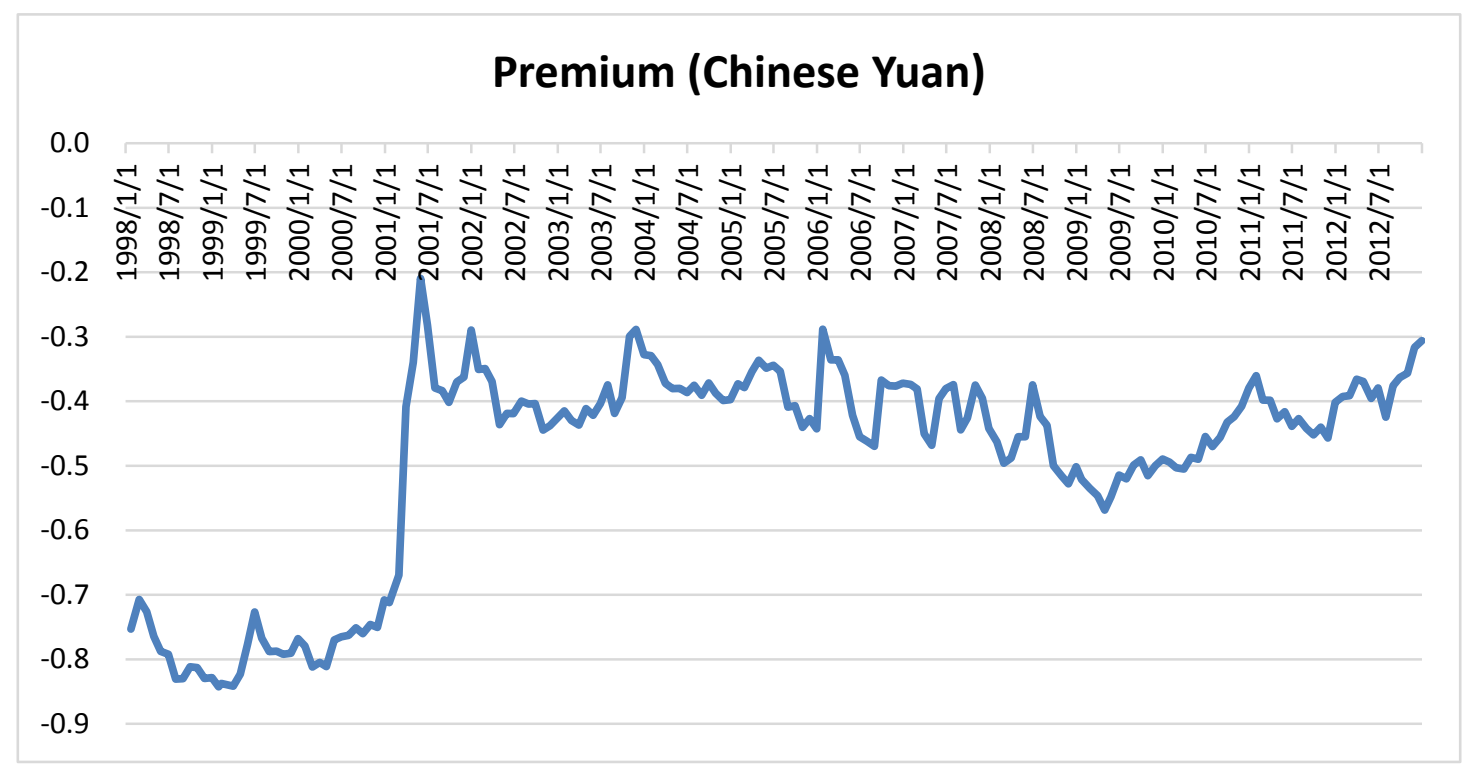

Figure 4. Plot of monthly premium

Figure 4 presents the average monthly premium; after 2001, premium substantially decreased, indicating that price spread between A- and B-shares fell. Nevertheless, the premium after July 2003 seems to fluctuate upwards and downwards.

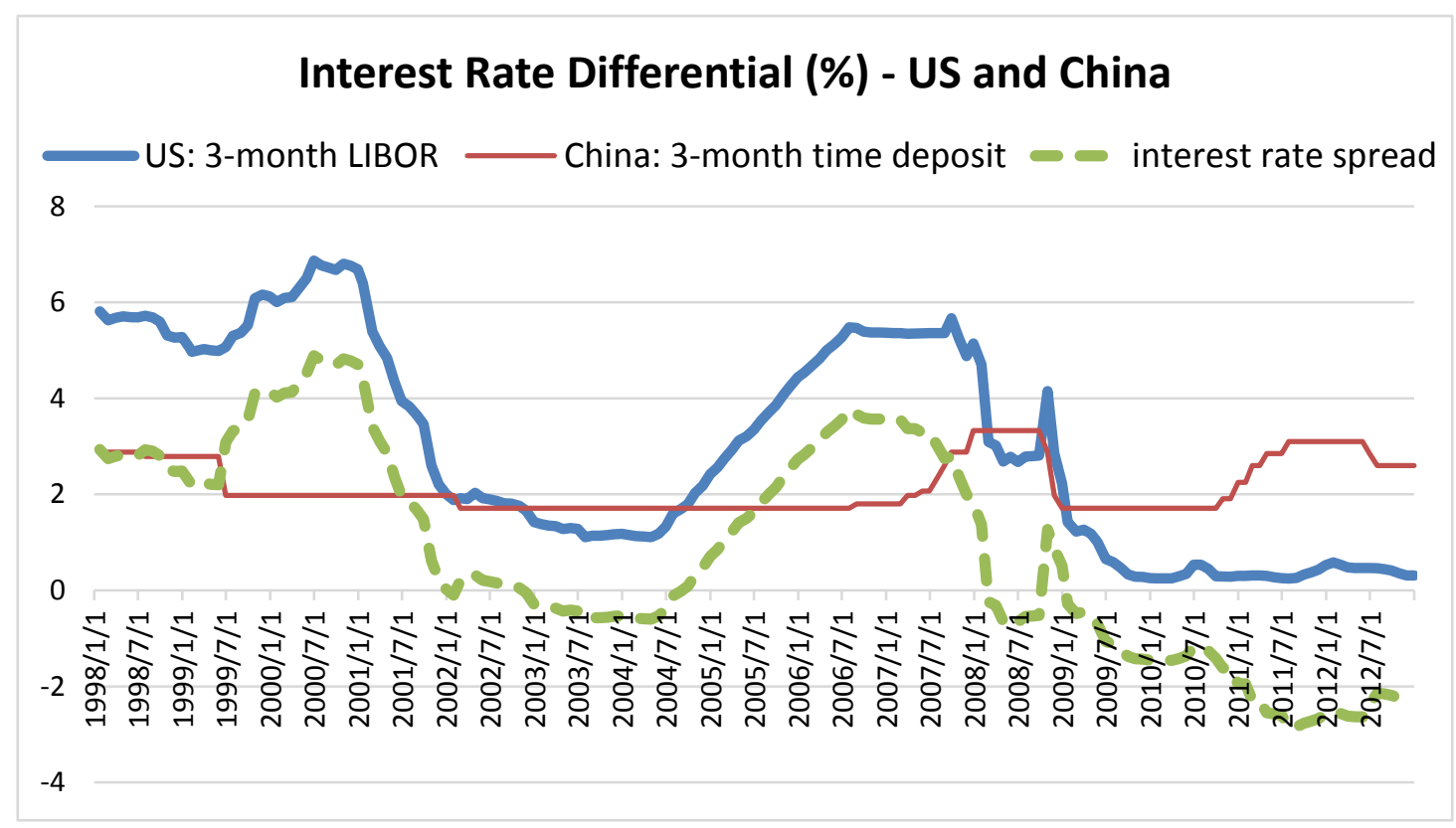

Figure 5. Plot of monthly interest rate differential - US and China 


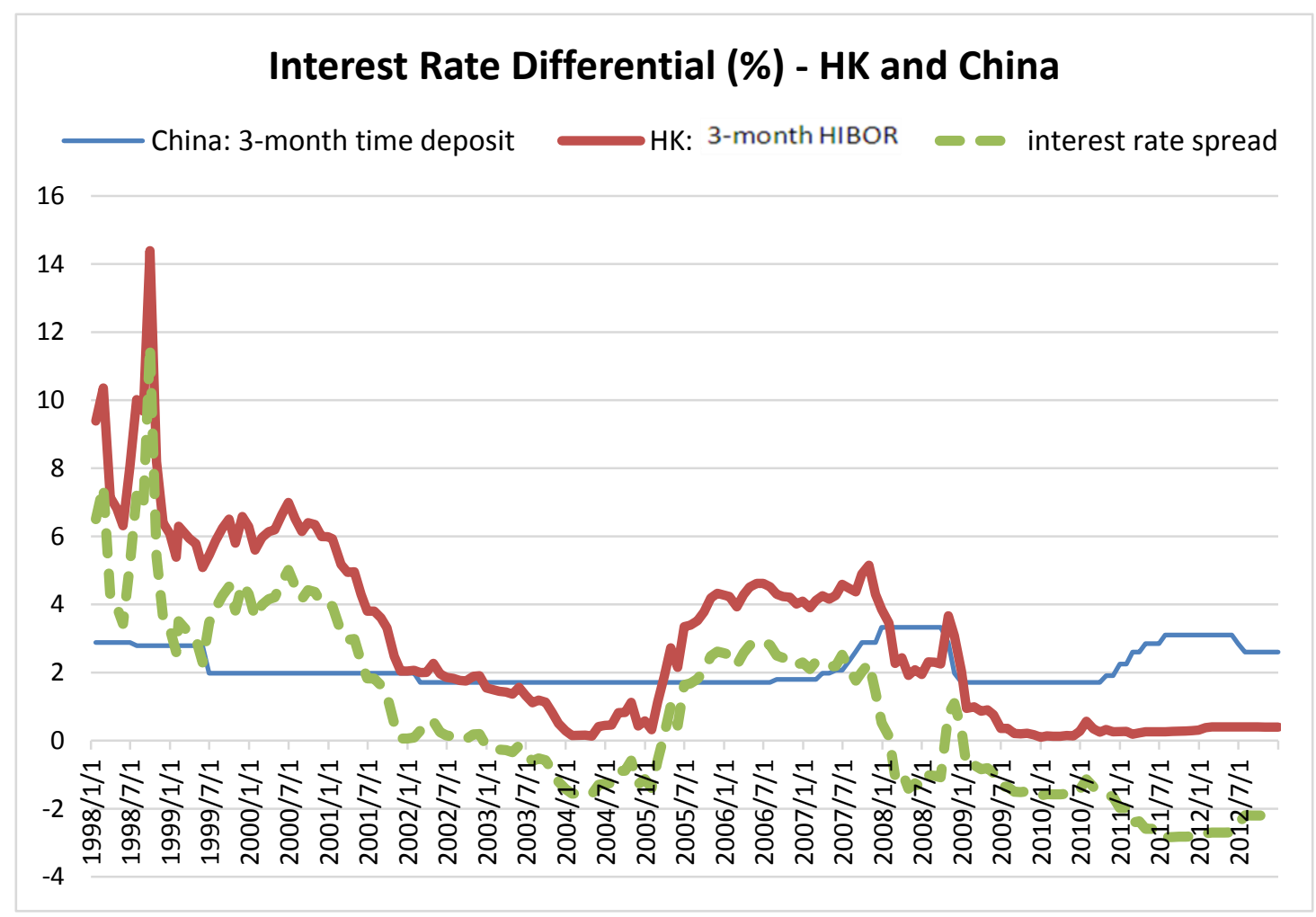

Figure 6. Plot of monthly interest rate differential - HK and China

Figures 5 and 6 illustrate that China's interest rate was relatively stable in comparison to those of the US and Hong Kong. The trends of interest rate differential are similar between the 3-month LIBORs of US and Hong Kong. Both the US and Hong Kong authorities decreased their discount rates since the 2007 subprime mortgage crisis and the subsequent financial crisis, which finally led to a negative interest rate spread.

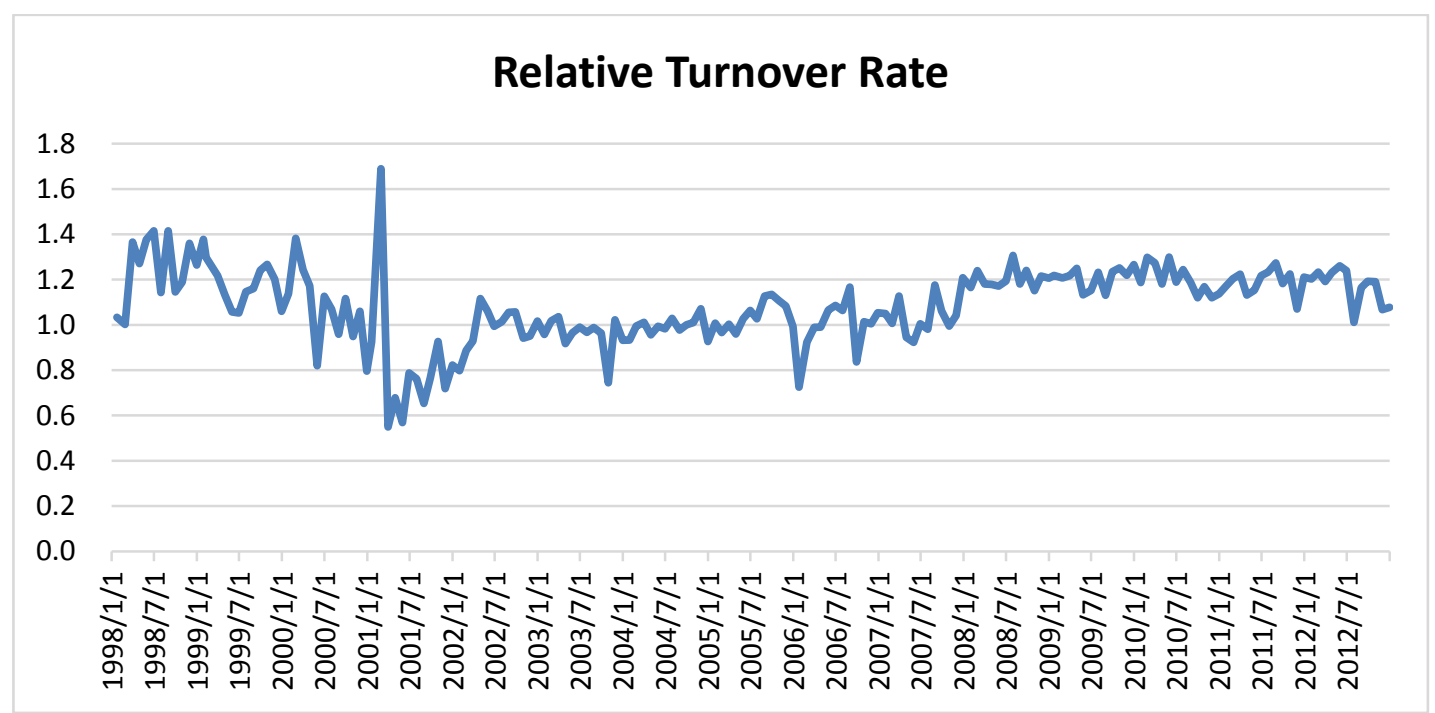

Figure 7. Plot of monthly relative turnover rate

Figure 7 shows that the average of monthly relative turnover rate has experienced slight growth since 2001, indicating that the turnover rate of B-shares has improved but since then, the average relative turnover rate moved up and down. 


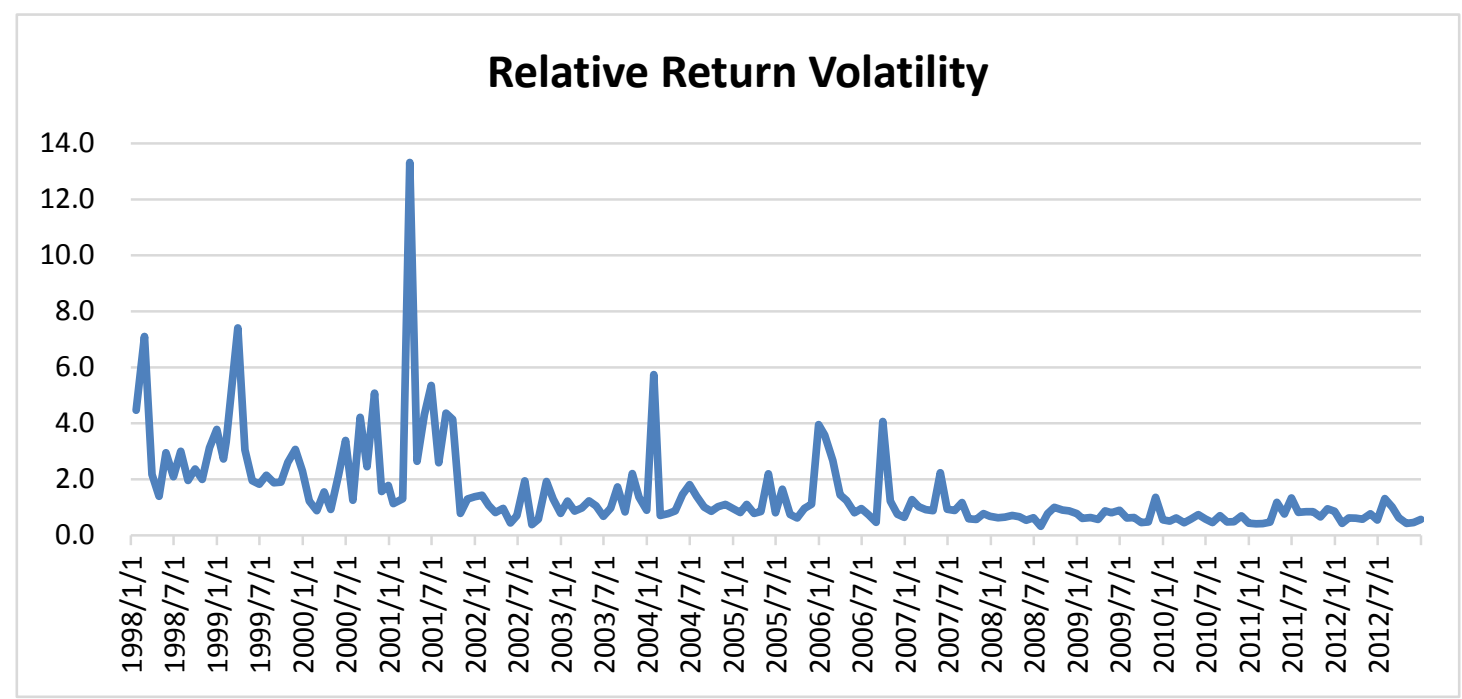

Figure 8. Plot of monthly relative return volatility

Figure 8 shows that average relative return volatility reached its peak in March 2001, a striking finding that may be attributable to the policy of opening the B-share market to local investors, leading to intensive speculation activities. Subsequently, the volatility of B-shares over A-shares is relatively small, which suggests that the B-share market became less volatile through the gradual liberalization process.

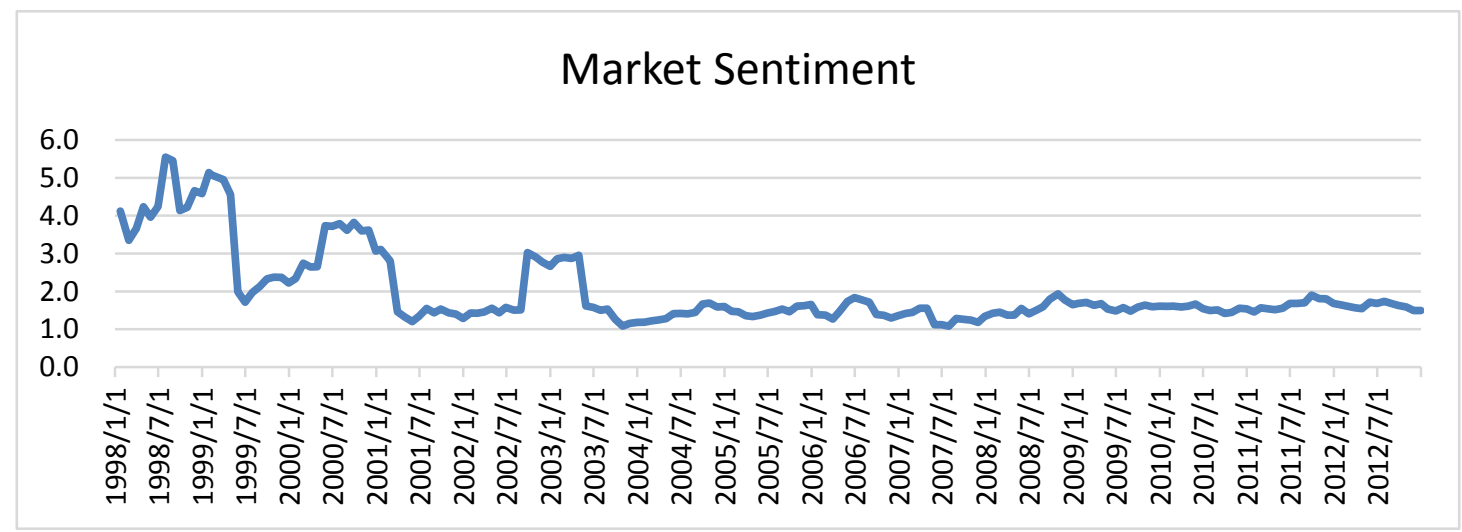

Figure 9. Plot of monthly market sentiment

It can be seen in Figure 9 that is always greater than one, suggesting that investors are relatively more enthusiastic in the A-shares than in the B-shares. However, since mid-2003, market sentiment has become relatively low and stable, which may imply that the behavior of B-shares has become subject to that of the A-shares after the implementation of QFII. 


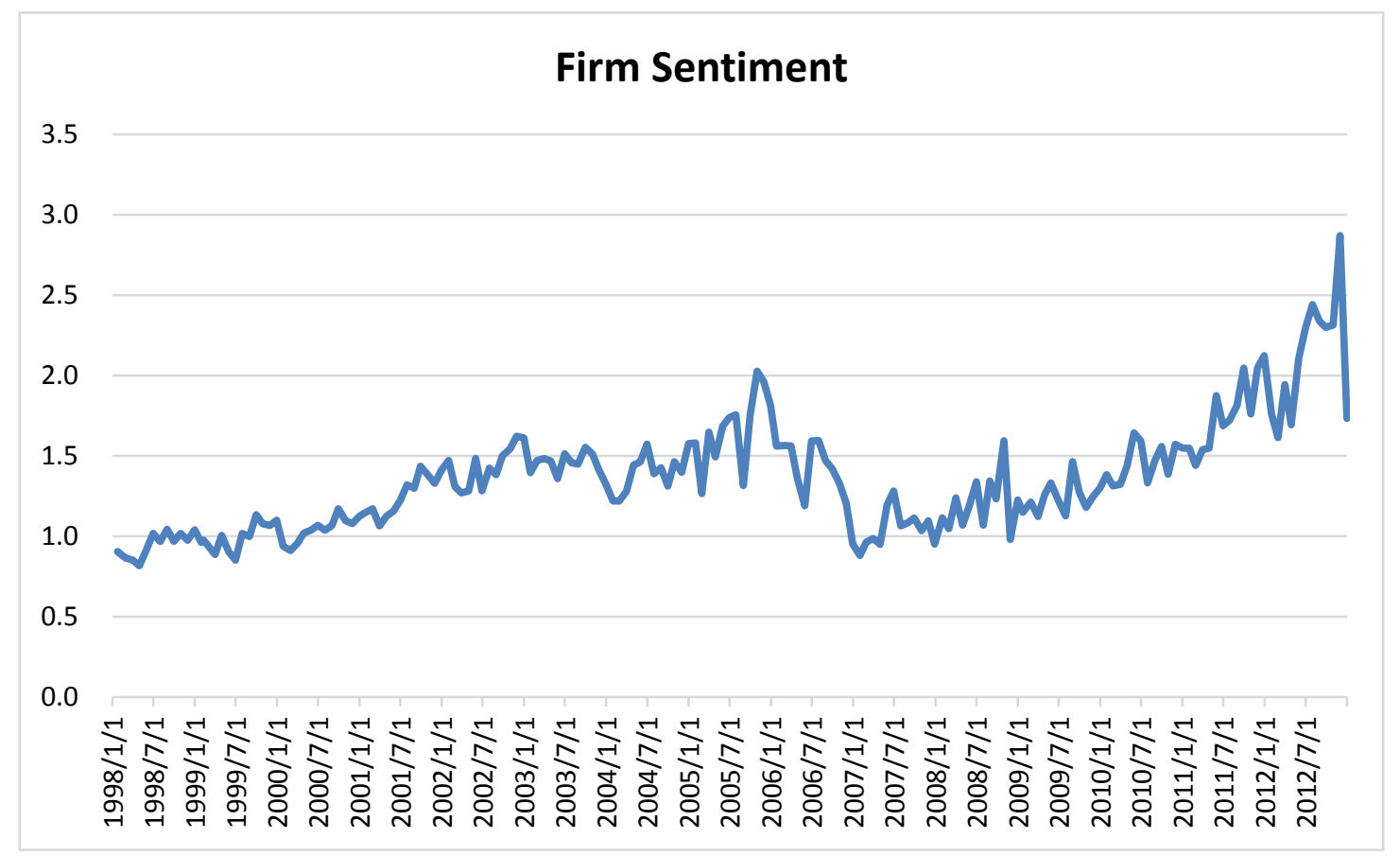

Figure 10. Plot of monthly firm sentiment

Average firm sentiment, as shown in Figure 10, has grown continuously since 2007, which seems to coincide with the structure break of the sub-prime mortgage crisis and the ensuing years.

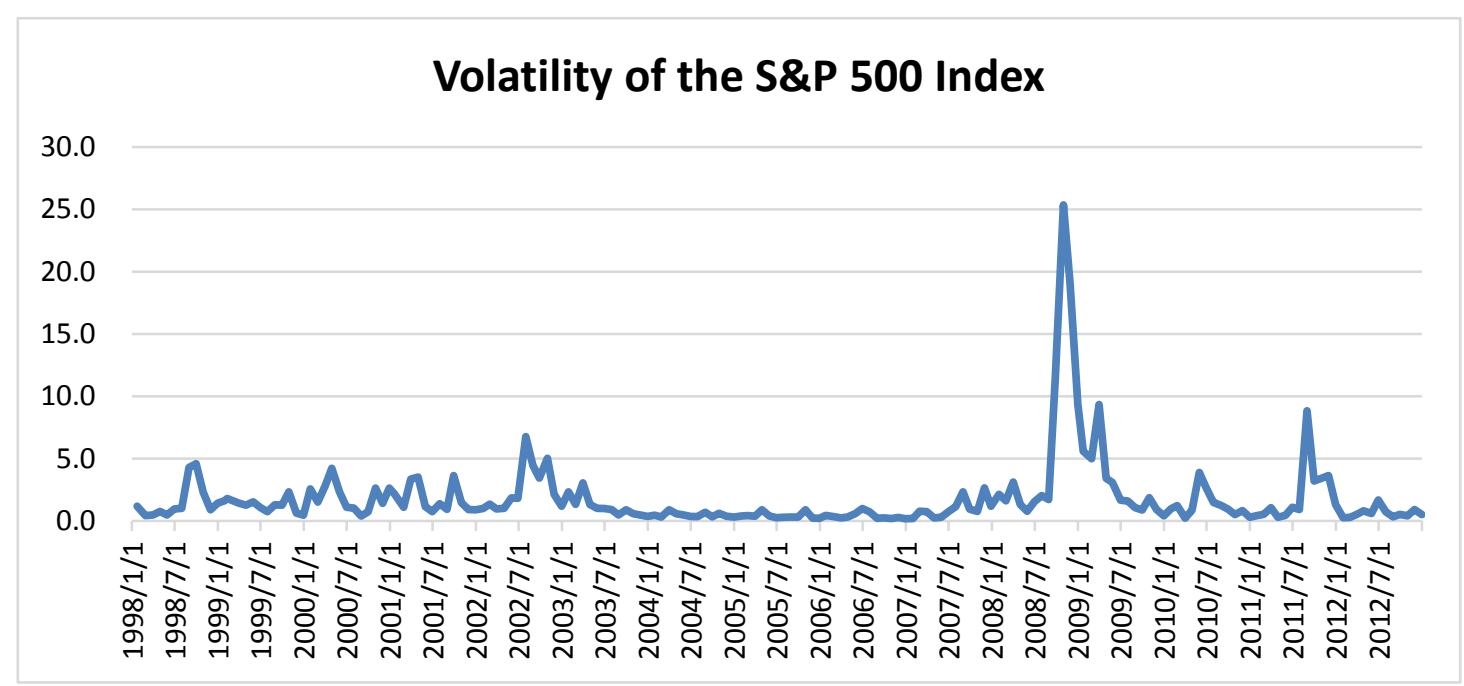

Figure 11. Plot of monthly volatility of the S\&P 500 Index

Figure 11 shows that there was a sharp increase at the end of 2008 when Lehman Brothers Holdings Inc. declared bankruptcy. This event was thought to have kicked off the late-2000s global financial crisis. Figure 12 represents the average market capitalization of all samples; data suggest that it has grown quite steady throughout the entire observation period. 


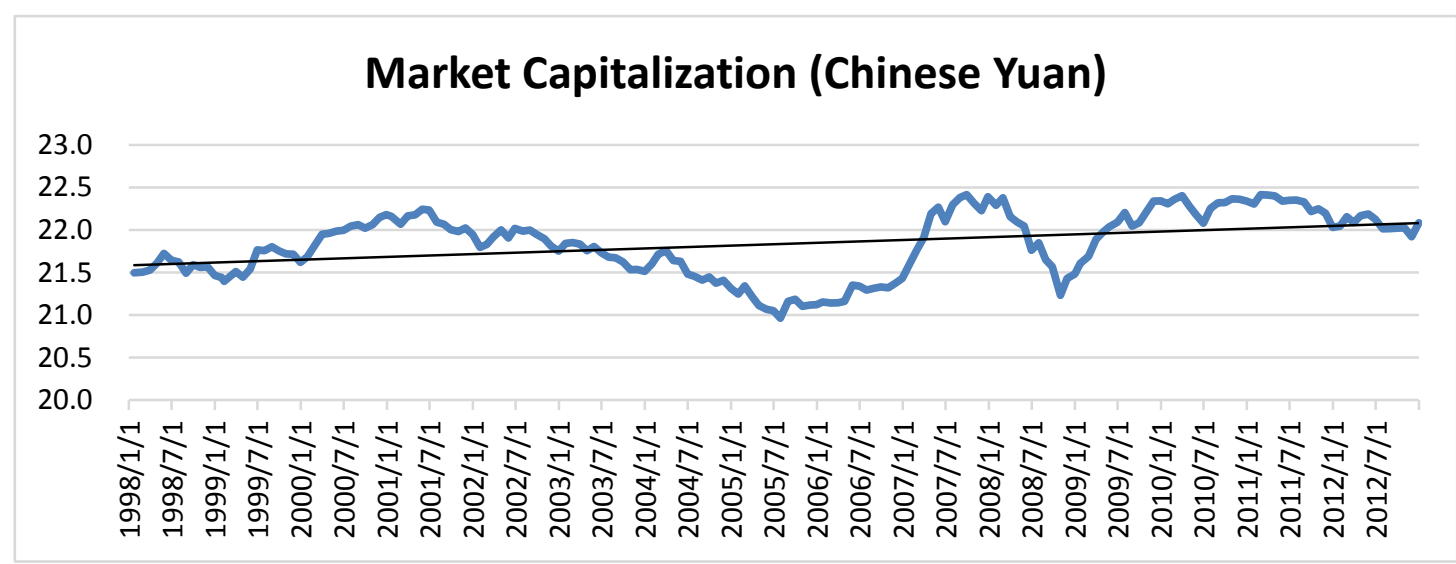

Figure 12. Plot of monthly market capitalization

\subsection{Panel Unit Root Test}

According to Granger \& Newbold (1974), if time-series data is not stationary, problems of spurious regression will appear, causing misjudgments in empirical results. To avoid such a phenomenon, we needed to confirm the time series to be stationary by conducting LLC and IPS panel unit root tests. We used the Schwarz criterion to select optimal lag length. The results are shown in Tables 1 and 2.

Table 1. Panel Unit Root Testing of the first period

\begin{tabular}{|c|c|c|c|}
\hline \multicolumn{4}{|c|}{ First Sub- Period } \\
\hline Variable: & None & With drift & $\begin{array}{l}\text { With drift and time } \\
\text { trend }\end{array}$ \\
\hline \multicolumn{4}{|c|}{ LLC unit root test } \\
\hline$\rho_{i t}$ & $-4.4843 * * *$ & $-17.5744 * * *$ & $-51.6557 * * *$ \\
\hline EX & $-40.1925 * * *$ & $-52.9849 * * *$ & $-62.2575 * * *$ \\
\hline PREM & $-8.0581 * * *$ & 1.86190 & 0.3715 \\
\hline IRD & $-7.74980 * * *$ & $-1.6997 *$ & $-3.0493 * * *$ \\
\hline RTR & $-5.8429 * * *$ & $-36.3775 * * *$ & $-47.2589 * * *$ \\
\hline RRV & $-21.2752 * * *$ & $-44.1611 * * *$ & $-49.5846 * * *$ \\
\hline MARKET & $-10.1032 * * *$ & $-4.0530 * *$ & $-6.1759 * * *$ \\
\hline FIRM & 2.5994 & -0.8295 & $-6.2352 * * *$ \\
\hline $\mathrm{R}_{\mathrm{US}}^{2}$ & $-16.1020^{* * *}$ & $-17.8543 * * *$ & $-15.3773 * * *$ \\
\hline CAP & 1.5904 & $-4.3225 * * *$ & $-1.9885^{*}$ \\
\hline \multicolumn{4}{|c|}{ IPS unit root test } \\
\hline$\rho_{i t}$ & - & $-16.6236^{* * *}$ & $-48.6012 * * *$ \\
\hline EX & - & $-42.2231 * * *$ & $-47.6458 * * *$ \\
\hline PREM & - & 4.5358 & -1.0320 \\
\hline IRD & - & 3.0467 & $-4.3811 * * *$ \\
\hline RTR & - & $-33.9780 * * *$ & $-41.2069 * * *$ \\
\hline RRV & - & $-43.0159 * * *$ & $-46.0587 * * *$ \\
\hline MARKET & - & $-1.3001^{*}$ & $-2.4749 * * *$ \\
\hline
\end{tabular}




\begin{tabular}{cccc}
\hline FIRM & - & -0.0529 & $-3.3261^{* * *}$ \\
\hline $\mathrm{R}_{\mathrm{US}}^{2}$ & - & $-32.5554^{* * *}$ & $-29.9476^{* * *}$ \\
\hline $\mathrm{CAP}$ & - & $-3.3011^{* * *}$ & $-2.7565^{*}$ \\
\hline
\end{tabular}

Source: the present study.

Note: ${ }^{*}$ p-value $<0.1, * *$ p-value $<0.05, * * *$ p-value $<0.01$

$\rho_{i t}$ : correlation between A- and B-shares of $\mathrm{i}^{\text {th }}$ firm; EX: exchange rate volatility; PREM: premium; IRD: interest rate differential; RTR: relative turnover rate; RRV: relative return volatility; MARKET: market sentiment; FIRM: firm sentiment; $\mathrm{R}_{\mathrm{US}}^{2}$ : volatility of S\&P 500 index; CAP: market capitalization

Table 2. Panel Unit Root Testing of the second period

\begin{tabular}{|c|c|c|c|}
\hline \multicolumn{4}{|c|}{ Second Sub-Period } \\
\hline Variable: & None & With drift & $\begin{array}{c}\text { With drift and time } \\
\text { trend }\end{array}$ \\
\hline \multicolumn{4}{|c|}{ LLC unit root test } \\
\hline$\rho_{i t}$ & $-5.1196 * * *$ & $-54.2122 * * *$ & $-70.4639 * * *$ \\
\hline EX & $-14.4602 * * *$ & $-60.1175^{* * *}$ & $-68.3561 * * *$ \\
\hline PREM & $-3.9618 * * *$ & $-10.6205^{* * *}$ & $-14.9099 * * *$ \\
\hline IRD & $-5.1957 * * *$ & 4.7187 & $-2.6608 * * *$ \\
\hline RTR & $-1.8232 * *$ & $-43.6761 * * *$ & $-64.4066 * * *$ \\
\hline RRV & $-18.9392 * * *$ & $-70.4297 * * *$ & $-84.7330 * * *$ \\
\hline $\mathrm{R}_{\mathrm{US}}^{2}$ & $-32.8377 * * *$ & $-35.2236 * * *$ & $-38.9990 * * *$ \\
\hline MARKET & $-4.0765 * * *$ & $-5.9173 * * *$ & $-4.4272 * * *$ \\
\hline FIRM & $-62.7858 * * *$ & $-72.4384 * * *$ & $-95.3982 * * *$ \\
\hline CAP & $-1.7889^{*}$ & $-6.3329 * * *$ & $-7.9530 * * *$ \\
\hline \multicolumn{4}{|c|}{ IPS unit root test } \\
\hline$\rho_{i t}$ & - & $-49.5752 * * *$ & $-56.9172 * * *$ \\
\hline EX & - & $-59.0337 * * *$ & $-61.5203 * * *$ \\
\hline PREM & - & $-11.0068^{* * *}$ & $-11.8077 * * *$ \\
\hline IRD & - & 7.5751 & 4.7030 \\
\hline RTR & - & $-40.8819 * * *$ & $-53.3780 * * *$ \\
\hline RRV & - & $-63.7286 * * *$ & $-70.4549 * * *$ \\
\hline MARKET & - & $-11.8639 * * *$ & $-8.1764 * * *$ \\
\hline FIRM & - & $-60.4635^{* * *}$ & $-73.2992 * * *$ \\
\hline $\mathrm{R}_{\mathrm{US}}^{2}$ & - & $-29.6783 * * *$ & $-26.5498 * * *$ \\
\hline CAP & - & $-1.6287^{*}$ & $-4.7745^{* *}$ \\
\hline
\end{tabular}

Source: the present study.

Note: The same note as the one in Table 1.

According to the results of IPS unit root testing in the first sample period (Table 1), premium (PREM) was not stationary and in the second sample period (Table 2), interest rate differential (IRD) was not stationary. After first differencing, both premium and interest rate differential appeared stationary. In the subsequent empirical analysis, we replaced premium by changes in premium $(\triangle \mathrm{PREM})$ in the first sample period and interest rate differential by changes in interest rate differential $(\triangle \mathrm{IRD})$ in the second sample period. 


\subsection{Selection of Models}

Table 3. Results of F/LM/Hausman Tests

\begin{tabular}{cccc}
\hline Sub-period & Cross-section F test & Breusch-Pagan LM & Hausman test \\
\hline $1^{\text {st }}$ & $2.7847 * * *$ & $79.5068 * * *$ & $25.4175^{* * * *}$ \\
\hline $2^{\text {nd }}$ & $4.703133 * * *$ & $314.2442 * * *$ & $21.760842 * * *$ \\
\hline
\end{tabular}

Source: the present study.

Note: $* * *$ p-value $<0.01$

According to the $\mathrm{F}$ tests, the null hypothesis was rejected for all samples, indicating that the fixed effects model was more appropriate than the pooled regression model. Based on the results of the Breusch-Pagan LM test, the random effects model was better than the pooled regression model for all samples. Therefore, Hausman test was used to compare the fixed effects model with the random effects model. We found the fixed effects model to be superior to the random effects model in two sub-periods. In addition, by considering residual heteroskedasticity we used White's heteroskedasticity consistent covariance to measure standard error. Incorporating this measure can make the significance test more conservative and reliable; if the residual is auto-correlated, ordinary least squares would not be suitable for estimating residual covariance matrix. Cross-section weights were utilized to reduce the sum of squared residuals. The empirical results are shown in the next subsection.

\subsection{Empirical Results}

After analyzing the results of Table 4, we can present some analyses regarding the coefficient estimates. The constant term represents the unconditional transformed correlation coefficient between A- and B-shares of individually listed firms. The result indicates that the unconditional transformed correlation coefficient varies from -0.7112 to -2.7652 . However, the variable of greater interest is the bilateral raw correlation coefficient. Hence, we must unscramble the transformation of the raw dependent variable in order to interpret the contribution of QFII's practical implementation to A- and B-share correlations of individual companies. The unscrambled correlation coefficient thus varied from -0.3413 for the pre-QFII period to -0.8815 for the post-QFII period, showing an increased bilateral correlation. This finding may correspond to more intensive arbitrage activities stimulated in the post-QFII period.

Table 4. Empirical results of Panel Data Model

\begin{tabular}{ccc}
\hline Variables & $\beta_{i}$ (First sub-period) & $\beta_{i}$ (Second sub-period) \\
\hline $\mathrm{C}$ & -0.7112 & $-2.7652^{* * *}$ \\
\hline EX & $-0.7939^{* * *}$ & 0.0132 \\
\hline PREM & 0.3213 & $0.8190^{* * *}$ \\
\hline IRD & $-0.1455^{* * *}$ & $-0.1346^{*}$ \\
\hline RTR & $-0.2353^{* *}$ & $0.6820^{* * *}$ \\
\hline RRV & $-0.0491^{* * *}$ & $-0.0211^{* *}$ \\
\hline MARKET & $-0.1087^{* * *}$ & $0.1793^{* *}$ \\
\hline FIRM & 0.0456 & $-0.0012^{*}$ \\
\hline $\mathrm{R}_{\mathrm{US}}^{2}$ & 0.0098 & $0.0239^{* * *}$ \\
\hline CAP & 0.1240 & $0.1508^{* * *}$ \\
\hline F-statistic & $35.3605^{* * *}$ & $26.4241^{* * *}$ \\
\hline Adjusted $\mathrm{R}^{2}$ & 0.3802 & 0.2085 \\
\hline DW & 1.7096 & 1.6518
\end{tabular}

Source: the present study. 
Note: $* \mathrm{p}$-value $<0.1,{ }^{* *} \mathrm{p}$-value $<0.05, * * * \mathrm{p}$-value $<0.01$. The empirical model is:

$$
\begin{gathered}
\rho_{\text {it }}=\beta_{0}+\beta_{1} \mathrm{EX}_{\mathrm{it}}+\beta_{2} \mathrm{PREM}^{+} \beta_{3} \mathrm{IRD}_{\mathrm{it}}+\beta_{4} \mathrm{RTR}_{\mathrm{it}}+\beta_{5} \mathrm{RRV}_{\mathrm{it}}+\beta_{6} \mathrm{MARKET}_{\mathrm{it}}+\beta_{7} \mathrm{FIRM}_{\mathrm{it}}+\beta_{8} \mathrm{R}_{\mathrm{US}, \mathrm{it}}^{2}+\beta_{9} \mathrm{CAP}_{\mathrm{it}} \\
+\mathrm{u}_{\mathrm{it}}
\end{gathered}
$$

$\rho_{i t}$ : correlation between A- and B-shares of $\mathrm{i}^{\text {th }}$ firm; EX: exchange rate volatility; PREM: premium; IRD: interest rate differential; RTR: relative turnover rate; RRV: relative return volatility; $\mathrm{R}_{\mathrm{US}}^{2}$ : volatility of S\&P 500 index; MARKET: market sentiment; FIRM: firm sentiment; CAP: market capitalization

Estimates of $\beta_{1}$ range from negative (-0.7939) to positive $(0.0132)$, which indicates that the exchange rate volatility was positively related to market correlation after QFII's implementation. Although this parameter is not statistically significant in the second period, it is basically consistent with our expectations. Premium had a significant impact on correlation and its magnitude increased a lot more in the $2^{\text {nd }}$ sub-period, demonstrating that when discount get less negative it may facilitate the interactions between A- and B-shares. With respect to the effect of interest rate differential, the smaller the $\triangle \mathrm{IRD}$ (change in interest rate differential), the stronger the correlation is between A- and B-shares.

In the second sub-period, the estimated value of $\beta_{4}$ changed from negative to positive, and the relative turnover rate appeared more important to market correlation than in the first sub-period. Based on this finding, when B-share's turnover was relatively higher than that of its A-share counterpart in the second sub-period, it may indicate that as relative turnover increases, market correlation raises. In other words, if QFII was able to improve the liquidity of a B-share, this would have helped increase the interaction between its returns and those of its corresponding A-share. As for relative return volatility, our findings indicate a negative relationship between market correlation and relative return volatility, regardless of whether the period examined was before or after QFII implementation. This is because the relative trading cost of B- and A-shares has narrowed down over the sample period, mainly corresponding to policies of opening B-shares to trade for domestic investors and of QFII scheme. Nevertheless, other factors may be responsible for the negative relation between relative return volatility and correlation.

As previously mentioned, the larger the market sentiment, the more the B-share discount became; based on previously discussed relatedness between PREM and correlation, it is reasonably predicted that market sentiment could be positively or negatively related to paired A- and B-share correlations. Empirical results show that market sentiment seemed more important to A- and B-share correlations in the second sub-period, when the estimated parameter $\beta_{6}$ moved from negative (-0.1087) to positive (0.1793). In contrast to market sentiment, firm sentiment was found to be marginally significant to correlation only in the second sub-period, and resulted in less impact on Aand B-share correlation than market sentiment. This is probably because individual firm's sentiment had been submerged mostly by market sentiment in the second sub-period as stock markets experienced several events and/or financial disasters, domestic or global.

Finally, both control variables, $\mathrm{R}_{\mathrm{US}}^{2}$ (the global factor) and firm size, were found to have an influence on correlation only during the second sub-period. We explain this finding by the notion that gradual deregulation of the financial market and foreign exchange rate could lead to China's integration into international stock markets and meanwhile firm size also contributed to correlation of paired A- and B-shares.

\section{Conclusions and Suggestions}

This paper was intended to examine some factors concerning the correlations of paired A- and B-shares of individual firms, and analyze the effects of QFII program's implementation on correlations. These are important issues but few studies were done on QFII's effect, particularly its implementation on correlations of paired A- and B-shares of individual firms. They are essential for international investment strategy and from policy-making perspective.

The empirical results show that interest rate differential, relative turnover rate, relative return volatility, and market sentiment had significant impact on correlation both before and after the implementation of the QFII program. In particular, after its implementation, correlations became more positively sensitive to premium, relative turnover rate and market sentiment. Among of them, premium exerts the largest impact on correlations, and hence, QFII's implementation could be one of factors narrowing down the price spread. It seems to support the price synchronicity and increase both A- and B-share liquidity, although market and firm sentiments may be related to premium. Regarding the relative return volatility, it has negative relation with correlations. As relative return volatility decreases, the relative trading cost differential becomes small, which may contribute to the increasing correlations. 
Furthermore, the estimated constant term for overall paired A- and B-share correlations became more negative (raw values from -0.3413 to -0.8815 ), indicating an increasing correlation partly subsequent to QFII implementation. Such a finding implies that investors could take advantage of a portfolio of paired A- and B-shares to diversify and may reduce more portfolio risk since the QFII's implementation. As for the effects of exchange rate volatility, it was not statistically significant in the second sub-period. This adds to another benefit of reducing cost of hedging risk when constructing portfolios including paired A- and B-shares.

As for this study, July 2003 was used as a dividing point. However, since July 2003, the Chinese government has formulated a series of important policies to improve the quality of its stock markets and keep removing barriers, such as the QDII program, split-share structure reforms, and allowing brokerage to offer the services of short selling, among others. It would be interesting for future research to examine how the interactions between paired A- and B-shares will be influenced by these liberalization programs.

\section{References}

Adam, K., Jappelli, T., Menichini, A., Padula, M., \& Pagano, M. (2001). Analyze, Compare, and Apply Alternative Indicators and Monitoring Methodologies to Measure the Evolution of Capital Market Integration in the European Union European, Commission Report.

Ahlgren, N., Sjö, B., \& Zhang, J. (2009). Panel Cointegration of Chinese A and B shares. Applied Financial Economics, 19(23), 1859-1871. https://doi.org/10.1080/09603100903122182

Amihud, Y., \& Mendelson, H. (1986). Asset Pricing and the Bid-ask Spread. Journal of financial Economics, 17(2), 223-249. https://doi.org/10.1016/0304-405X(86)90065-6

Arquette, G. C., Brown Jr, W. O., \& Burdekin, R. C. (2008). US ADR and Hong Kong H-share Discounts of Shanghai-listed Firms. Journal of Banking and Finance, 32(9), 1916-1927. https://doi.org/10.1016/j.jbankfin.2007.12.019

Baele, L., Ferrando, A., Hördahl, P., Krylova, E., \& Monnet, C. (2004). Measuring Financial Integration in the Euro Area. ECB Occasional Paper 12.

Bekaert, G., \& Harvey, C. R. (1997). Emerging Equity Market Volatility (No. w5307). National Bureau of Economic Research.

Bekaert, G., \& Harvey, C. (2003). Emerging Markets Finance. Journal of Empirical Finance, 10, 3-55. https://doi.org/10.1016/S0927-5398(02)00054-3

Bodart, V., \& Reding, P. (1999). Exchange Rate Regime, Volatility and International Correlations on Bond and Stock Markets. Journal of International Money and Finance, 18(1), 133-151. https://doi.org/10.1016/S0261-5606(98)00042-4

Bollerslev, T. (1990). Modelling the Coherence in Short-run Nominal Exchange Rates: A Multivariate Generalized ARCH Model. The Review of Economics and Statistics, 72(3), 498-505. https://doi.org/10.2307/2109358

Breusch, T. S., \& Pagan, A. R. (1980). The Lagrange Multiplier Test and its Applications to Model Specification in Econometrics. The Review of Economic Studies, 47(1), 239-253. https://doi.org/10.2307/2297111

Cappiello, L., Engle, R. F., \& Sheppard, K. (2006). Asymmetric Dynamics in the Correlation of Global Equity and Bond Returns. Journal of Financial Econometrics, 4, 537-572. https://doi.org/10.1093/jjfinec/nbl005

Chan, J. S., Hong, D., \& Subrahmanyam, M. G. (2008). A Tale of Two Prices: Liquidity and Asset Prices in Multiple Markets. Journal of Banking and Finance, 32(6), 947-960. https://doi.org/10.1016/j.jbankfin.2007.07.002

Chan, K., Hameed, A., \& Kang, W. (2013). Stock Price Synchronicity and Liquidity. Journal of Financial Markets, 16(3), 414-438. https://doi.org/10.1016/j.finmar.2012.09.007

Chen, C. F., \& Liu, S. W. (2009). Stock Price Interaction and Price Differential between Dually-Listed A- and B-Shares in China's Stock Market: A Comparison Before and After the B-Share's Opening Policy. Journal of Financial Studies, 15(2), 139-162. (Chinese edition)

Chiu, C. L., Lee, M., \& Chen, C. D. (2005). Removal of an Investment Restriction: the 'B'share Experience from China's Stock Markets. Applied Financial Economics, 15(4), 273-285. https://doi.org/10.1080/0960310042000314232

Dang, T. L., Moshirian, F., \& Zhang, B. (2015). Commonality in News around the World. Journal of Financial Economics, 116, 82-110. https://doi.org/10.1016/j.jfineco.2014.11.007 
Granger, C. W., \& Newbold, P. (1974). Spurious Regressions in Econometrics. Journal of Econometrics, 2(2), 111-120. https://doi.org/10.1016/0304-4076(74)90034-7

He, H., Chen, S., Yao, S., \& Ou, J. (2014). Financial Liberalisation and International Market Interdependence: Evidence from China's Stock Market in the post-WTO Accession Period. Journal of International Financial Markets, Institutions and Money, 33, 434-444. https://doi.org/10.1016/j.intfin.2014.09.005

He, Y., Wu, C., \& Chen, Y.-M. (2003). An Explanation of the Volatility Disparity between the Domestic and Foreign Shares in the Chinese Stock Markets. International Review of Economics and Finance, 12, 171-186. https://doi.org/10.1016/S1059-0560(03)00003-0

Henry, P. B. (2002). Stock Market Liberalization, Economic Reform, and Emerging Market Equity Prices. The Journal of Finance, 55(2), pp. 529-564. https://doi.org/10.1111/0022-1082.00219

Huang, B. N., \& Yang, C. W. (2000). The Impact of Financial Liberalization on Stock Price Volatility in Emerging Markets. Journal of Comparative Economics, 28(2), 321-339. https://doi.org/10.1006/jcec.2000.1651

Huang S. J. (2007). Empirical Study on the Influence of QFII on Stock Market of China. Economic and Trade Update, 5(11X), 171-172. (Chinese edition)

Im, K. S., Pesaran, M. H., \& Shin, Y. (2003). Testing for Unit Roots in Heterogeneous Panels. Journal of Econometrics, 115(1), 53-74. https://doi.org/10.1016/S0304-4076(03)00092-7

Jithendranathan, T. (2005). What Causes Correlations of Equity Returns to Change Over Time? A Study of the US and the Russian Equity Markets. Investment Management and Financial Innovations, 4, 69-79.

Kassimatis, K. (2002). Financial Liberalization and Stock Market Volatility in Selected Developing Countries. Applied Financial Economics, 12(6), 389-394. https://doi.org/10.1080/09603100010001937

Knif, J., \& Pynnonen, S. (2007). Volatility Driven Changes in Stock Return Correlation Dynamics. Managerial Finance, 33(3), 220-235. https://doi.org/10.1108/03074350710718293

Law, S. H., \& Ngahab, W. A. S. W. (2008). Does Stock Market Liberalization Cause Higher Volatility in the Bursa Malaysia?. International Journal of Business and Society, 9(1), 19-36.

Levin, A., Lin, C. F., \& Chu, C. S. J. (2002). Unit Root Tests in Panel Data: Asymptotic and Finite-sample Properties. Journal of Econometrics, 108(1), 1-24. https://doi.org/10.1016/S0304-4076(01)00098-7

Li, Q. (2002). Market Opening and Stock Market Behavior: Taiwan's Experience. International Journal of Business and Economics, 1(1), 9-15.

Li, Y., Yan, D., \& Greco, J. (2006). Market Segmentation and Price Differentials between A Shares and H Shares in the Chinese Stock Markets. Journal of Multinational Financial Management, 16(3), 232-248. https://doi.org/10.1016/j.mulfin.2005.07.003

Llorente, G., Michaely, R., Saar, G., \& Wang, J. (2002). Dynamic Volume-Return Relation of Individual Stocks. Review of Financial Studies, 15(4), 1005-1047. https://doi.org/10.1093/rfs/15.4.1005

Lu, L., \& Su, C. (2008). An Analysis of QFII's Investment Behavior on Stability of Chinese Securities Markets. Journal of Hubei University of Economics: Humanities and Social Sciences, 5(12), 53-55. (Chinese edition)

Otto, G., Voss, G. M., \& Willard, L. (2001). Understanding OECD Output Correlations. Reserve Bank of Australia.

Peng T. (2008). The Effect of QFII on Stock Market Volatility. ZHIDU JINGJIXUE YAN JIU, (3), 138-152. (Chinese edition)

Pontiff, J. (1996). Costly Arbitrage: Evidence from Closed-End Funds. The Quarterly Journal of Economics, 111(4), 1135-1151. https://doi.org/10.2307/2946710

Shen, C. H., \& Chen, C. F. (2003). Does B-Share's Opening Influence the Efficiency of Chinese Stock Market? An Application of Asymmetric Threshold Cointegration. Journal of Financial Studies, 11(3), 89-119. (Chinese edition)

Shen X. W., \& Lan, F. Q. (2007). The Impact of QFII Program on Chinese Stock Markets. Economists, 2, 127-128. (Chinese edition)

Sun, Q., Tong, W. H., \& Yan, Y. (2009). Market Liberalization within a Country. Journal of Empirical Finance, 16(1), 18-41. https://doi.org/10.1016/j.jempfin.2008.07.003

Tam, O. K., Li, S. G., Zhang, Z., \& Yu, C. P. (2010). Foreign Investment in China and Qualified Foreign 
Institutional Investor (QFII). Asian Business and Management, 9(3), 425-448. (Chinese edition). https://doi.org/10.1057/abm.2010.15

Wälti, S. (2011). Stock Market Synchronization and Monetary Integration. Journal of International Money and Finance, 30(1), 96-110. https://doi.org/10.1016/j.jimonfin.2010.07.004

Wang, S. S., \& Jiang, L. (2004). Location of Trade, Ownership Restrictions, and Market Illiquidity: Examining Chinese A- and Hshares. Journal of Banking \& Finance, 28, 1273-1297. https://doi.org/10.1016/S0378-4266(03)00119-5

Wang, X. L., \& Han L. Y. (2008). A Comparative Analysis of Volatility in Chinese A-and B-Shares Market in QFII. Journal of Beijing University of Aeronautics and Astronautics (Social Sciences Edition), 22(3), 4-6. (Chinese edition)

Wei, S-J. (2000). Noise Trading in the Chinese Stock Market. In Chen, Baizhu, Dietrich, J., Kimball, \& Feng, Yi (Eds.), Financial Market Reform in China: Progress, Problems, and Prospects (pp. 221-241). Westview Press, Boulder, CO.

Young, P., \& Johnson, R. R. (2004). Bond Market Volatility versus Stock Market Volatility: The Swiss Experience. Financial Markets and PortfolioManagement, 18(1), 8-23. https://doi.org/10.1007/s11408-004-0102-4

Zou, L.,Tang, T., \& Li, X. (2016). The Stock Preferences of Domestic versus Foreign Investors: Evidence from Qualified Foreign Institutional Investors (QFIIs) in China. Journal of Multinational Financial Management, 37-38, 12-28. https://dx.doi.org/10.1016/j.mulfin.2016.11.002

\section{Note}

Note 1. Measures of market quality include illiquidity, volatility, transaction costs, bid-ask spread and price premium. 